\title{
Effect of Post-Harvest Dipping and Various Packaging Materials on Quality Traits of Mandarin (Citrus Reticulata Blanco.)
}

\author{
Anup Paudel*, Dhruba Baral, Himal Acharya, Madhav Dhital \\ Agriculture and Forestry University, Rampur, Chitwan, Nepal \\ *Corresponding author email: anuppaudel305@gmail.com
}

\section{DOI: 10.2478/acmy-2019-0007}

\begin{abstract}
:
An experiment was carried out to study the effect of post-harvest dipping and various packaging materials on quality traits of mandarin at the laboratory of Project Implementation Unit (Citrus zone) Udayapur, Katari from January to February 2019. The parameters observed were physiological loss in weight, juice content, titrable acidity, total soluble solids, TSS/TA ratio and shelf life. The packaging materials include individual newspaper wrapping, perforated polyethene and corrugated box. Gibberellic acid with a concentration of $100 \mathrm{ppm}$ was used as a dipping material. The experiment was laid out in Completely Randomized Design (CRD) with 8 treatment replicated 3 times. The result showed that among eight treatments combination, fruits treated with GA3 in combination with perforated polyethene recorded minimum physiological loss in weight $(1.99 \%)$ and control $(19.08 \%)$. High retention of juice content $(40.30 \%)$, total soluble solids(12.83 Gbrix) and titrable acidity $(0.60 \%)$ was recorded in fruits treated with GA3 in combination with perforated polyethene in 24 days of storage. Fruits treated with GA3 in combination with perforated polyethene attained shelf life of 48 days followed by perforated polyethene with a shelf life of 44 days. Finding of the experiment may prove to be helpful in rural area to store mandarin with minimum loss as markets are far from the village.
\end{abstract}

Keywords: Citrus, gibberellic acid, combination, attributes

\subsection{Introduction:}

Citrus fruits are grown in subtropics and tropics regions of the world. It is grown commercially in the subtropical region of Nepal. Citrus is widely grown throughout the mid- hills (900-1400 masl) from east to west across the country [1]. 146 countries in the world are producing 139.79 million mt of citrus from the 9.08-million-hectare area in the world [2]. China is the leading country with $>24 \%$ of the world's total citrus production. In Nepal citrus is grown successfully in more than 55 districts and occupies $20^{\text {th }}$ position in the world's mandarin production [3]. Mandarin alone covers $67 \%$ of the total productive area and $64 \%$ of the total production [4]. In subtropical regions, citrus fruits are produced distant from consumer markets and often must be stored for the market economy. According to a study conducted, the citrus fruits imported only from India are Mandarin $(9,51,100 \mathrm{~kg}), \mathrm{lime}(17,89,110 \mathrm{~kg})$, sweet orange $(2,64,095 \mathrm{~kg})$ [5]. Due to the long duration between harvest and consumption, there is postharvest loss due to pathological and physiological diseases. Nearly $20-25 \%$ of mandarin fruits are wasted due to faulty postharvest management [6]. At room temperature, the postharvest shelf life of man darin is 2 3 weeks and fruits sold at this condition leads to huge qualitative and quantitative losses [7]. The postharvest losses can be minimized with the help of the extension of shelf life through lowering and checking the rate of transpiration, respiration, microbial infection and protecting membranes from disorganization.

The application of various chemicals either alone or in combination with different packaging materials may be used for extending post-harvest shelf life of mandarin during storage [8]. Packaging of fruits can result in the creation of a modified atmosphere due to ineffective blockage of the pores within the fruits, reducing respiration rate and improving postharvest quality [9]. There are certain chemicals like PGR, botanical extract etc. which reduce the ethylene production (respiration rate) and growth of micro-organism so as to increase the shelf life of mandarin. Since use or packaging materials in farmers level and in other retail market are new in Udayapur districts. Plant growth regulators like 2-4 D, GA $\mathrm{A}_{3}$ are also used to decrease the fungus infestation. However, the role of these packaging alone or in combination with pre-storage treatment needed much focus on correlating the positive mode of applicability to mandarin. The main objective of this research was to enhance post-harvest life of mandarin by using different packaging materials and post-harvest dipping.

\subsection{Materials and Methods}

The present research was carried out at laboratory of Project Implementation Unit (Citrus zone) Udayapur, Katari from January to February 2019.

\subsection{Selection and harvest of fruits}

The fresh mandarin fruits of Khoku variety were selected and harvested by clipper keeping with small pedicel intact of fruit and collected in crates from the orchard.

\subsection{Details of the experiment}

The experiment was laid out in Completely Randomized Design (CRD). A total of 36 fruits per treatment were divided into equal lots for all three replication and each replication of treatment consists of 12 fruits. The treated fruits were kept for storage and observed at 3 days interval up to 24 days.

\subsection{Packaging and dipping for fruits}

The packaging materials used in this experiment were Corrugated boxes $(27 \mathrm{~cm} \times 13 \mathrm{~cm} \times 10 \mathrm{~cm})$, perforated polyethylene $25-\mathrm{micron} \mathrm{LDPE}(30 \mathrm{~cm} \times 20 \mathrm{~cm})$ with a diameter of perforation $5 \mathrm{~mm}$ ( 2 in each polyethene), newspaper $(30 \mathrm{~cm} \times 20 \mathrm{~cm})$. For the preparation of $100 \mathrm{ppm} \mathrm{GA}_{3}$ solution, $1 \mathrm{~g}$ of GA 3 with active ingredient $90 \% \mathrm{w} / \mathrm{w}$ were dissolved in $10 \mathrm{ml}$ of solvent prepared from dissolving solvent crystals in distilled water. Thereafter, 9 liters of distilled water was added to it. Fruits were separately dipped for 5 minutes in $\mathrm{GA}_{3}$ solution in a bucket. Dipped fruits were dried again under the shed over the newspaper.

\section{Treatments details}

$\mathrm{T}_{1} \quad$ Open

$\mathrm{T}_{2} \quad \mathrm{GA3}(100 \mathrm{ppm})$

$\mathrm{T}_{3} \quad$ Perforated plastic packaging

$\mathrm{T}_{4} \quad$ Corrugated Box
$\mathrm{T}_{5} \quad$ Individual Newspaper wrapping

$\mathrm{T}_{6} \quad \mathrm{GA} 3(100 \mathrm{PPm})+$ Perforated Plastic Packaging

$\mathrm{T}_{7} \quad \mathrm{GA3}(100 \mathrm{ppm})+$ Corrugated Box

$\mathrm{T}_{8} \quad \mathrm{GA3}(100 \mathrm{ppm})+$ Individual Newspaper wrapping

\subsection{OBSERVATION}

Observations were recorded in 3 days interval for 24 days. Physical and chemical quality attributes were taken in each three days interval. 
Physiological loss in weight (\% loss in weight from the initial weight) and

Juice content (\% of juice weight to fruits weight).

\subsection{Chemical quality attributes}

Total soluble solids ( ${ }^{\circ}$ Brix),

Titrable acidity (\%)

TSS: acid ratio

On the basis of the procedure the observation was taken [10]. On the basis of marketable acceptability shelf life (days) was determined. The data pertaining to various parameters were collected at different stages and intervals and tabulated in an Excel sheet for analysis. All routine statistical analysis was carried out using Genstat software $15^{\text {th }}$ Edition. Means were compared using Duncan's Multiple Range Test (DMRT) at 0.05 and 0.01 levels of significance [11].

\subsection{Temperature \& $\mathbf{R H}$}

Temperature and $\mathrm{RH}$ was recorded each day during the experimental period using thermo-hygrometer. $(18.12 \pm 0.97)^{\circ} \mathrm{C}$ mean temperature and $(68.21 \pm$ 1.56) \% humidity.

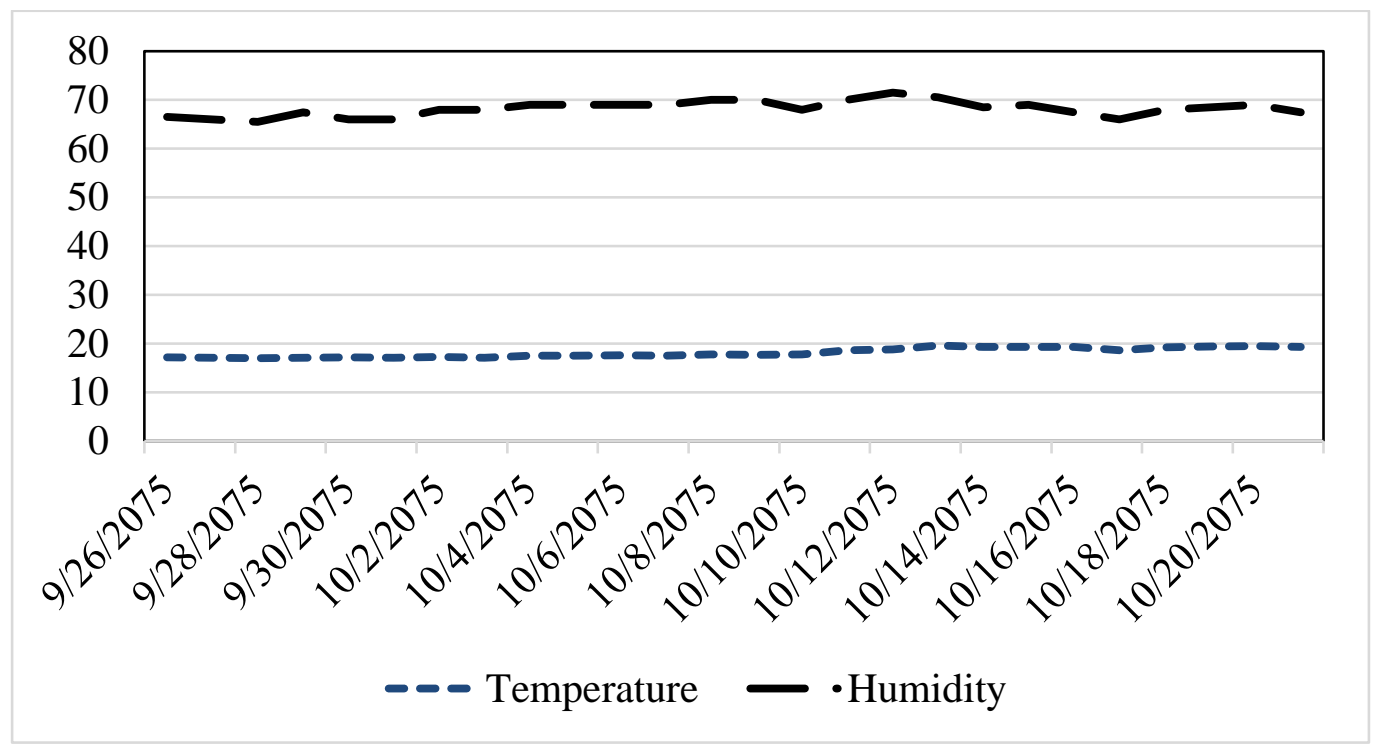

Figure 1: Climatic parameter of experimental lab

\subsection{Results and Discussion}

\subsection{Physiological loss in weight (PLW)}

Significant differences existed among different post-harvest treatments for physiological loss in weight with the advancement of the storage period. Fruit treated with $\mathrm{GA}_{3}$ in combination with Perforated polyethene recorded minimum percentage of PLW during the whole storage period and the losses ranged from $0.24 \%$ in $3^{\text {rd }}$ day to $1.99 \%$ in $24^{\text {th }}$ day whereas maximum weight loss was recorded in the fruits with untreated as control (3.19\% to $19.08 \%$ ) which was followed by $\mathrm{GA}_{3}$ treated (2.59\% to $16.86 \%$ ), followed by newspaper wrapping which was statistically at par with the finding of GA3 in combination with newspaper wrapping is shown in Table 1.

Physiological loss in weight during period of storage is characterized by a reduction in fruit weight by the way of loss of moisture through evaporation and/or transpiration. Physiological loss in weight is the most important parameter because it governs the post-harvest quality of the fruits. Among different post-harvest treatments, $\mathrm{GA}_{3}$ at $100 \mathrm{ppm}$ in combination with perforated polyethene recorded the lowest PLW followed by perforated polyethene might be due to retardation of transpiration and respiration losses from fruits. A possible explanation for lower PLW in the mandarin fruits obtained in the present study could be that perforated polyethene and corrugated boxes provide better protective cover as compared to newspaper wrapping which perhaps helps in lower PLW of mandarin fruits. These packaging materials might have lowered the temperature surrounding the fruits thereby reducing evapotranspiration of the fruits.GA3 treatment in combination with perforated polyethene and other packaging material is due to $\mathrm{GA}_{3}$ reduces the incidence of fungus and thus retaining resistance of fruit to the decay pathogen [12-16].

Table 1: Effect of post-harvest dipping and packaging on physiological weight loss (\%) of mandarin fruit during storage at ambient condition (18.12 \pm $0.97)^{\circ} \mathrm{C}$ mean temperature and (68.21 \pm 1.56$) \% \mathrm{RH}$, Udayapur, Nepal, (2019)

\begin{tabular}{llllllll}
\hline \multirow{2}{*}{ Treatments } & \multicolumn{5}{c}{ The physiological loss in weight (\%) on days indicated } \\
\cline { 2 - 7 } & 3 DOS & 6 DOS & 9 DOS & 12 DOS & 15 DOS & 18 DOS & 24 DOS \\
\hline Control & $3.192^{\mathrm{a}}$ & $6.2^{\mathrm{a}}$ & $9.03^{\mathrm{a}}$ & $11.38^{\mathrm{a}}$ & $13.53^{\mathrm{a}}$ & $16.16^{\mathrm{a}}$ & $19.08^{\mathrm{a}}$ \\
$\mathrm{GA}_{3}(100 \mathrm{ppm})$ & $2.592^{\mathrm{b}}$ & $5.42^{\mathrm{a}}$ & $7.97^{\mathrm{a}}$ & $10.29^{\mathrm{a}}$ & $12.05^{\mathrm{ab}}$ & $14.06^{\mathrm{b}}$ & $16.86^{\mathrm{b}}$ \\
$\begin{array}{l}\text { Perforated } \\
\begin{array}{l}\text { Polyethene } \\
\text { Corrugated Box }\end{array}\end{array}$ & $0.239^{\mathrm{e}}$ & $0.47^{\mathrm{d}}$ & $0.77^{\mathrm{d}}$ & $1.48^{\mathrm{d}}$ & $1.90^{\mathrm{e}}$ & $2.08^{\mathrm{f}}$ & $2.38^{\mathrm{f}}$ \\
& $2.168^{\mathrm{bc}}$ & $4.16^{\mathrm{b}}$ & $5.82^{\mathrm{b}}$ & $7.13^{\mathrm{b}}$ & $8.62^{\mathrm{c}}$ & $9.66^{\mathrm{d}}$ & $10.69^{\mathrm{d}}$
\end{tabular}




\begin{tabular}{|c|c|c|c|c|c|c|c|}
\hline $\begin{array}{l}\text { Newspaper } \\
\text { wrapping } \\
\text { (individual) }\end{array}$ & $1.982^{\mathrm{bc}}$ & $4.10^{\mathrm{b}}$ & $6.21^{b}$ & $8.31^{b}$ & $10.10^{\mathrm{bc}}$ & $12.10^{\mathrm{c}}$ & $13.76^{c}$ \\
\hline $\begin{array}{l}\mathrm{GA}_{3}(100 \mathrm{ppm})+ \\
\text { Perforated } \\
\text { Polyethene }\end{array}$ & $0.237 \mathrm{e}$ & $0.51^{\mathrm{d}}$ & $0.56^{\mathrm{d}}$ & $1.05^{d}$ & $1.40^{\mathrm{e}}$ & $1.76^{\mathrm{f}}$ & $1.99^{f}$ \\
\hline $\begin{array}{l}\mathrm{GA}_{3}(100 \mathrm{ppm})+ \\
\text { Corrugated Box }\end{array}$ & $1.298^{\mathrm{d}}$ & $2.49^{c}$ & $3.51^{\mathrm{c}}$ & $4.54^{c}$ & $5.46^{d}$ & $7.15^{\mathrm{e}}$ & $8.51^{\mathrm{e}}$ \\
\hline $\begin{array}{l}\mathrm{GA}_{3}(100 \mathrm{ppm})+ \\
\text { Newspaper } \\
\text { wrapping } \\
\text { Individual }\end{array}$ & $1.929^{c}$ & $4.31^{b}$ & $6.49^{b}$ & $8.41^{b}$ & $10.24^{\mathrm{bc}}$ & $12.16^{\mathrm{c}}$ & $13.94^{c}$ \\
\hline $\operatorname{SEm}( \pm)$ & 0.1947 & 0.305 & 0.419 & 0.505 & 0.626 & 0.557 & 0.519 \\
\hline $\operatorname{LSD}(=0.05)$ & $0.5837^{* *}$ & $0.913^{* *}$ & $1.255^{* *}$ & $1.513^{* *}$ & $1.876^{* *}$ & $1.670^{* *}$ & $1.556^{* *}$ \\
\hline $\mathrm{CV}, \%$ & 19.8 & 15.2 & 14.4 & 13.3 & 13.7 & 10.3 & 8.2 \\
\hline P-value & $<0.001$ & $<0.001$ & $<0.001$ & $<0.001$ & $<0.001$ & $<0.001$ & $<0.001$ \\
\hline Grand mean & 1.704 & 3.46 & 5.05 & 6.57 & 7.91 & 9.39 & 10.90 \\
\hline
\end{tabular}

Means in column followed by common letters is not significantly different at $5 \%$ level of significance, Level of significance ${ }^{\prime * * ’} 0.01$, ‘*’0.05, NS=nonsignificant DOS= Days of Storage, CV= co-efficient of variation, $\mathrm{LSD}=$ least significant difference, $\mathrm{SEm}=\mathrm{standard}$ error of mean.

\subsection{Juice content}

Table 2 shows that the juice content percentage decreased with the time during the storage in all the treatments but was not significantly lower to 12 days of storage. At $24^{\text {th }}$ days of storage, $\mathrm{GA}_{3}(100 \mathrm{ppm})+$ Perforated polyethene treated fruits recorded the maximum juice content percentage (40.30\%) which was statistically at par with the findings of perforated polyethene followed by $\mathrm{GA}_{3}(100 \mathrm{ppm})+$ newspaper wrapping which was statistically at par with the findings of $\mathrm{GA}_{3}(100 \mathrm{ppm})+$ corrugated box, corrugated box, newspaper wrapping whereas the minimum juice content percentage(32.63\%) was observed in control fruits.

The trend of decrease in juice percentage during the storage was might be due to loss of moisture from the surface of the fruits. GA3 treated fruits with perforated polyethene showed a low reduction in juice content during storage as compared to control or other treatments. This might be due to the fact that polyethene acted as a barrier which had checked the losses of the moisture from the fruit surface. A group researhcers reported higher juice recovery percentage in PE-packed fruits (T10) followed by the fruits with 100\% Sta-Fresh 960 (T4) which might be due to less water loss in PE-packaging and waxing treatments as the combination acts as a barrier to moisture loss [17]. $\mathrm{GA}_{3}$ treatment delay the degradation of starch and also maintain the freshness of peel which lowers the loss of moisture from the peel of citrus result in higher juice content in $\mathrm{GA}_{3}$ treated fruits [18-20].

Table 2: Effect of post-harvest dipping and packaging on juice recovery (\%) of mandarin fruit during storage at ambient condition $(18.12 \pm 0.97)^{\circ} \mathrm{C}$ mean temperature and (68.21 \pm 1.56$) \%$ RH, Udayapur, Nepal, (2019)

\begin{tabular}{|c|c|c|c|c|c|c|c|}
\hline \multirow[t]{2}{*}{ Treatments } & \multicolumn{7}{|c|}{ Juice recovery $\%$ of fruit on days indicated } \\
\hline & $3 \mathrm{DOS}$ & $6 \mathrm{DOS}$ & 9 DOS & 12 DOS & 15 DOS & 18 DOS & 24 DOS \\
\hline Control & 40.71 & 40.54 & 39.90 & 37.61 & $35.90^{\mathrm{c}}$ & $33.70^{\mathrm{e}}$ & $32.63^{\mathrm{d}}$ \\
\hline $\mathrm{GA}_{3}(100 \mathrm{ppm})$ & 39.57 & 40.91 & 41.49 & 38.81 & $36.65^{\mathrm{bc}}$ & $34.26^{\mathrm{e}}$ & $34.12^{\mathrm{cd}}$ \\
\hline Perforated Polyethene & 45.05 & 43.88 & 42.17 & 41.02 & $40.98^{\mathrm{a}}$ & $40.40^{\mathrm{ab}}$ & $40.02^{\mathrm{a}}$ \\
\hline Corrugated Box & 44.11 & 42.54 & 39.90 & 39.44 & $38.51^{\mathrm{abc}}$ & $37.37^{\mathrm{cd}}$ & $35.56^{\mathrm{bc}}$ \\
\hline $\begin{array}{l}\text { Newspaper wrapping } \\
\text { (individual) }\end{array}$ & 39.54 & 40.84 & 38.92 & 37.18 & $37.06^{\mathrm{bc}}$ & $36.54^{\mathrm{d}}$ & $34.27^{\mathrm{bcd}}$ \\
\hline $\begin{array}{l}\mathrm{GA}_{3}(100 \mathrm{ppm})+\text { Perforated } \\
\text { Polyethene }\end{array}$ & 44.61 & 42.29 & 41.65 & 41.34 & $40.90^{\mathrm{a}}$ & $40.86^{\mathrm{a}}$ & $40.30^{\mathrm{a}}$ \\
\hline $\begin{array}{l}\mathrm{GA}_{3}(100 \mathrm{ppm})+\text { Corrugated } \\
\text { Box }\end{array}$ & 41.64 & 40.14 & 39.83 & 40.44 & $39.38^{\mathrm{ab}}$ & $38.61^{\mathrm{bc}}$ & $35.69^{\mathrm{bc}}$ \\
\hline $\begin{array}{l}\mathrm{GA}_{3}(100 \mathrm{ppm})+\text { Newspaper } \\
\text { wrapping Individual }\end{array}$ & 40.67 & 41.75 & 39.36 & 38.36 & $38.37 \mathrm{abc}$ & $36.96^{\mathrm{cd}}$ & $36.67^{b}$ \\
\hline $\operatorname{SEm}( \pm)$ & 1.688 & 1.671 & 1.557 & 1.495 & 0.957 & 0.611 & 0.755 \\
\hline $\operatorname{LSD}(=0.05)$ & NS & NS & NS & NS & $2.869^{*}$ & $1.832^{* *}$ & $2 . .263^{* *}$ \\
\hline $\mathrm{CV}, \%$ & 7.0 & 7.0 & 6.7 & 6.6 & 4.3 & 2.8 & 3.6 \\
\hline P-value & 0.154 & 0.780 & 0.755 & 0.459 & 0.012 & $<0.001$ & $<0.001$ \\
\hline Grand mean & 41.99 & 41.61 & 40.40 & 39.19 & 38.47 & 37.34 & 36.16 \\
\hline
\end{tabular}

Means in column followed by common letters is not significantly different at $5 \%$ level of significance, Level of significance ${ }^{\prime * * \prime} 0.01$, $^{\prime * \prime} 0.05$, NS=nonsignificant DOS= Days of Storage, $\mathrm{CV}=$ co-efficient of variation, $\mathrm{LSD}=$ least significant difference, $\mathrm{SEm}=$ standard error of means 


\subsection{Total Soluble Solids (TSS)}

Table 3. shows the increasing trend is higher in untreated (control), $\mathrm{GA}_{3}$ treated and newspaper wrapping than the fruits with perforated polyethene packaging. Fruits which are untreated showed the maximum TSS content during the storage period and ranged from $11.60^{\circ} \mathrm{brix}$ during $3^{\text {rd }}$ day to $14.20^{\circ} \mathrm{brix}$ during $24^{\text {th }}$ day which was statistically at par with $\mathrm{GA}_{3}$ treated fruits and minimum TSS content was recorded in the fruits treated with $\mathrm{GA}_{3}$ in combination with perforated polyethene packaging. In control, TSS was increased at a faster pace, this might be due to faster metabolic activities through respiration and transpiration than in the other treatment's combination. The increase in TSS with the advancement of storage may be accounted to the moisture loss, hydrolysis of polysaccharides and concentration of juice as a result of dehydration [21].

Table 3: Effect of post-harvest dipping and packaging on total soluble solids (TSS) of mandarin fruit during storage at ambient condition $(18.12 \pm 0.97)^{\circ} \mathrm{C}$ mean temperature and (68.21 \pm 1.56$) \% \mathrm{RH}$, Udayapur, Nepal, (2019)

\begin{tabular}{|c|c|c|c|c|c|c|c|}
\hline \multirow[t]{2}{*}{ Treatments } & \multicolumn{7}{|c|}{ TSS of fruits on days indicated } \\
\hline & 3DOS & 6DOS & 9DOS & 12DOS & 15DOS & 18DOS & 24DOS \\
\hline Control & 11.60 & 11.93 & 12.27 & 12.93 & 13.07 & $13.70^{\mathrm{a}}$ & $14.20^{\mathrm{a}}$ \\
\hline $\mathrm{GA}_{3}(100 \mathrm{ppm})$ & 11.53 & 11.53 & 11.87 & 12.80 & 12.90 & $13.60^{\mathrm{a}}$ & $13.73^{\mathrm{ab}}$ \\
\hline Perforated Polyethene & 11.13 & 11.60 & 12.10 & 12.07 & 12.40 & $12.67 \mathrm{bc}$ & $13.26^{\mathrm{bc}}$ \\
\hline Corrugated Box & 11.33 & 11.80 & 11.90 & 12.30 & 12.57 & $13.40^{\mathrm{ab}}$ & $13.76^{\mathrm{ab}}$ \\
\hline Newspaper wrapping (individual) & 11.43 & 11.33 & 12.03 & 12.73 & 12.53 & $13.07 \mathrm{abc}$ & $13.67^{\mathrm{ab}}$ \\
\hline $\begin{array}{l}\mathrm{GA}_{3}(100 \mathrm{ppm})+\text { Perforated } \\
\text { Polyethene }\end{array}$ & 10.67 & 11.47 & 11.73 & 11.90 & 12.13 & $12.33^{c}$ & $12.83^{\mathrm{c}}$ \\
\hline $\mathrm{GA}_{3}(100 \mathrm{ppm})+$ Corrugated Box & 11.67 & 11.63 & 11.83 & 12.80 & 12.87 & $12.93^{\mathrm{abc}}$ & $13.36^{\mathrm{bc}}$ \\
\hline $\begin{array}{l}\mathrm{GA}_{3}(100 \mathrm{ppm})+\text { Newspaper } \\
\text { wrapping (Individual) }\end{array}$ & 11.53 & 12.10 & 12.00 & 12.73 & 12.80 & $12.87 \mathrm{abc}$ & $13.50^{\mathrm{abc}}$ \\
\hline $\operatorname{SEm}( \pm)$ & 0.579 & 0.353 & 0.527 & 0.378 & 0.2333 & 0.267 & 0.233 \\
\hline $\operatorname{LSD}(=0.05)$ & NS & NS & NS & NS & NS & $0.8018^{*}$ & $0.6977^{*}$ \\
\hline $\mathrm{CV}, \%$ & 8.8 & 5.2 & 7.6 & 5.2 & 3.2 & 3.5 & 3 \\
\hline P-value & 0.934 & 0.809 & 0.997 & 0.46 & 0.175 & 0.029 & 0.032 \\
\hline Grand mean & 11.36 & 11.68 & 11.97 & 12.50 & 12.658 & 13.071 & 13.542 \\
\hline
\end{tabular}

Means in column followed by common letters is not significantly different at $5 \%$ level of significance, Level of significance ${ }^{` * * \prime} 0.01,{ }^{\prime *}{ }^{\prime} 0.05$, NS=nonsignificant DOS= Days of Storage, $\mathrm{CV}=$ co-efficient of variation, $\mathrm{LSD}=$ least significant difference, $\mathrm{SEm}=$ standard error of means.

\subsection{Titrable Acidity}

As data presented in Table 4, the TA was significantly decreased from 18 days of storage. Higher acidity was recorded in the fruits treated with $\mathrm{GA}_{3}$ in combination with perforated polyethene packaging which was 0.69 on $3^{\text {rd }}$ day of storage and 0.60 on $24^{\text {th }}$ day of storage period whereas there was a significant decrease in the titrable acidity content of the fruits left untreated which was 0.68 on $3^{\text {rd }}$ days of storage and 0.52 on $24^{\text {th }}$ day of storage period. The decreasing trend of titrable acidity during the storage period probably due to the utilization of acid in the tricarboxylic acid cycle in the respiration process. On $24^{\text {th }}$ days of storage higher acidity was in the fruit treated with $\mathrm{GA}_{3}$ in combination with perforated polyethene packaging which was significantly at par with the finding of perforated polyethene, $\mathrm{GA}_{3}$ in combination with corrugated box $[22,23]$.

Table 4: Effect of post-harvest dipping and packaging on titrable acidity (TA) of mandarin fruit during storage at ambient condition $(18.12 \pm 0.97)^{\circ} \mathrm{C}$ mean temperature and (68.21 \pm 1.56$) \%$ RH, Udayapur, Nepal, (2019)

\begin{tabular}{|c|c|c|c|c|c|c|c|}
\hline \multirow[t]{2}{*}{ Treatments } & \multicolumn{7}{|c|}{ Titrable acidity (\%) on days indicated } \\
\hline & 3DOS & 6DOS & 9DOS & 12DOS & 15DOS & 18DOS & 24DOS \\
\hline Control & 0.68 & 0.64 & 0.60 & 0.57 & 0.57 & $0.55^{\mathrm{c}}$ & $0.52^{\mathrm{d}}$ \\
\hline $\mathrm{GA}_{3}(100 \mathrm{ppm})$ & 0.69 & 0.65 & 0.62 & 0.60 & 0.58 & $0.56^{\mathrm{bc}}$ & $0.54^{\mathrm{cd}}$ \\
\hline Perforated Polyethene & 0.69 & 0.68 & 0.66 & 0.64 & 0.61 & $0.59^{a}$ & $0.58^{\mathrm{abc}}$ \\
\hline Corrugated Box & 0.70 & 0.66 & 0.61 & 0.61 & 0.59 & $0.58^{\mathrm{ab}}$ & $0.56^{\mathrm{bcd}}$ \\
\hline Newspaper wrapping (individual) & 0.69 & 0.65 & 0.60 & 0.60 & 0.58 & $0.57^{\mathrm{abc}}$ & $0.55^{\mathrm{bcd}}$ \\
\hline $\mathrm{GA}_{3}(100 \mathrm{ppm})+$ Perforated Polyethene & 0.69 & 0.69 & 0.67 & 0.66 & 0.62 & $0.60^{\mathrm{a}}$ & $0.60^{\mathrm{a}}$ \\
\hline $\mathrm{GA}_{3}(100 \mathrm{ppm})+$ Corrugated Box & 0.69 & 0.66 & 0.61 & 0.62 & 0.59 & $0.58^{\mathrm{ab}}$ & $0.58^{\mathrm{ab}}$ \\
\hline
\end{tabular}


ISSN: 2576-6732 (Print)

\begin{tabular}{llllllll}
\hline $\begin{array}{l}\mathrm{GA}_{3}(100 \mathrm{ppm})+\text { Newspaper wrapping } \\
\text { Individual }\end{array}$ & 0.70 & 0.66 & 0.61 & 0.61 & 0.58 & $0.58^{\mathrm{ab}}$ & $0.57^{\mathrm{abc}}$ \\
\hline $\mathrm{SEm}( \pm)$ & 0.0179 & 0.013 & 0.0178 & 0.0209 & 0.01197 & 0.01037 & 0.0120 \\
LSD (=0.05) & $\mathrm{NS}$ & $\mathrm{NS}$ & $\mathrm{NS}$ & $\mathrm{NS}$ & $\mathrm{NS}$ & $0.03109^{*}$ & $0.0361^{*}$ \\
$\mathrm{CV}, \%$ & 4.5 & 3.5 & 4.9 & 5.9 & 3.5 & 3.1 & 3.7 \\
P-value & 0.99 & 0.116 & 0.062 & 0.209 & 0.141 & 0.028 & 0.005 \\
Grand mean & 0.69 & 0.66 & 0.62 & 0.61 & 0.59 & 0.58 & 0.56 \\
\hline
\end{tabular}

Means in column followed by common letters is not significantly different at $5 \%$ level of significance, Level of significance '**’0.01, ‘*’0.05, NS=nonsignificant DOS= Days of Storage, $\mathrm{CV}=$ co-efficient of variation, $\mathrm{LSD}=$ least significant difference, $\mathrm{SEm}=\mathrm{standard}$ error of means

\subsection{TSS: TA ratio}

TSS: TA ratio of mandarin fruit as influenced by a different combination of treatments is depicted in Table 5. The effect of treatment was significant with respect to TSS: TA ratio. At the beginning of the storage period from $3^{\text {rd }}$ day to $12^{\text {th }}$ day no significant differences were observed among the treatments. From $12^{\text {th }}$ to $24^{\text {th }}$ day of storage significant differences among the treatments were observed. On the $24^{\text {th }}$ day of storage, the significantly maximum ratio was observed with untreated fruits (27.20) while the minimum ratio was observed with GA 3 treated fruits in combination with perforated polyethene packaging (21.27).

Table 5: Effect of post-harvest dipping and packaging on TSS/TA ratio of mandarin fruit during storage at ambient condition (18.12 \pm 0.97$){ }^{\circ} \mathrm{C}$ mean temperature and (68.21 \pm 1.56$) \%$ RH, Udayapur, Nepal, (2019)

\begin{tabular}{|c|c|c|c|c|c|c|c|}
\hline \multirow[t]{2}{*}{ Treatments } & \multicolumn{7}{|c|}{ TSS/TA on days indicated } \\
\hline & 3DOS & 6DOS & 9DOS & 12DOS & 15DOS & 18DOS & $24 \mathrm{DOS}$ \\
\hline Control & 17.02 & 18.71 & 20.46 & $22.68^{a}$ & $23.14^{a}$ & $24.89^{a}$ & $27.20^{\mathrm{a}}$ \\
\hline $\mathrm{GA}_{3}(100 \mathrm{ppm})$ & 16.44 & 17.85 & 19.30 & $21.24^{\mathrm{ab}}$ & $22.17^{\mathrm{ab}}$ & $24.42^{\mathrm{ab}}$ & $25.37^{\mathrm{ab}}$ \\
\hline Perforated Polyethene & 16.10 & 16.93 & 18.31 & $18.82^{\mathrm{bc}}$ & $20.05^{\mathrm{cd}}$ & $20.91^{\mathrm{de}}$ & $22.46^{\mathrm{cd}}$ \\
\hline Corrugated Box & 16.09 & 17.86 & 19.39 & $20.32^{\mathrm{abc}}$ & $21.12^{\mathrm{bcd}}$ & $23.09 \mathrm{bc}$ & $24.55^{\mathrm{bc}}$ \\
\hline Newspaper wrapping (individual) & 16.60 & 17.31 & 19.94 & $21.08^{\mathrm{ab}}$ & $21.13^{\mathrm{bcd}}$ & $22.94^{\mathrm{c}}$ & $25.07^{b}$ \\
\hline $\begin{array}{l}\mathrm{GA}_{3}(100 \mathrm{ppm})+\text { Perforated } \\
\text { Polyethene }\end{array}$ & 15.40 & 16.53 & 17.42 & $18.05^{c}$ & $19.49^{d}$ & $20.29 \mathrm{e}$ & $21.27^{\mathrm{d}}$ \\
\hline $\mathrm{GA}_{3}(100 \mathrm{ppm})+$ Corrugated Box & 16.98 & 17.62 & 19.25 & $20.76^{\mathrm{abc}}$ & $21.31^{\mathrm{bc}}$ & $22.05^{\mathrm{cd}}$ & $22.87^{\mathrm{cd}}$ \\
\hline $\begin{array}{l}\mathrm{GA}_{3}(100 \mathrm{ppm})+\text { Newspaper } \\
\text { wrapping Individual }\end{array}$ & 16.57 & 18.30 & 19.86 & $20.31^{\mathrm{abc}}$ & $21.90^{\mathrm{ab}}$ & $22.36^{\mathrm{cd}}$ & $23.84^{b c}$ \\
\hline $\operatorname{SEm}( \pm)$ & 0.798 & 0.623 & 0.862 & 0.876 & 0.536 & 0.465 & 0.674 \\
\hline $\operatorname{LSD}(=0.05)$ & NS & NS & NS & $2.625^{*}$ & $1.606^{* *}$ & $1.394^{* *}$ & $2.021^{* *}$ \\
\hline $\mathrm{CV}, \%$ & 8.4 & 6.1 & 7.8 & 7.4 & 4.4 & 3.6 & 4.8 \\
\hline P-value & 0.861 & 0.313 & 0.330 & 0.047 & 0.005 & $<0.001$ & $<0.001$ \\
\hline Grand mean & 16.40 & 17.64 & 19.24 & 20.41 & 21.29 & 22.62 & 24.08 \\
\hline
\end{tabular}

Means in column followed by common letters is not significantly different at $5 \%$ level of significance, Level of significance ${ }^{\prime * * ’} 0.01$, ‘*’0.05, NS=nonsignificant DOS= Days of Storage, CV= co-efficient of variation, LSD= least significant difference, SEm= standard error of means

\subsection{Shelf life (no of days)}

\section{Treatments}

Control

GA3(100ppm)

Perforated Polyethene

Corrugated Box

Newspaper wrapping (individual)

GA3(100ppm) + Perforated Polyethene

GA3(100ppm) + Corrugated Box

\section{Storability (Days)}

26

27

44

42

35

48

43

GA3(100ppm) + Newspaper wrapping Individual 


\section{Shelf life}

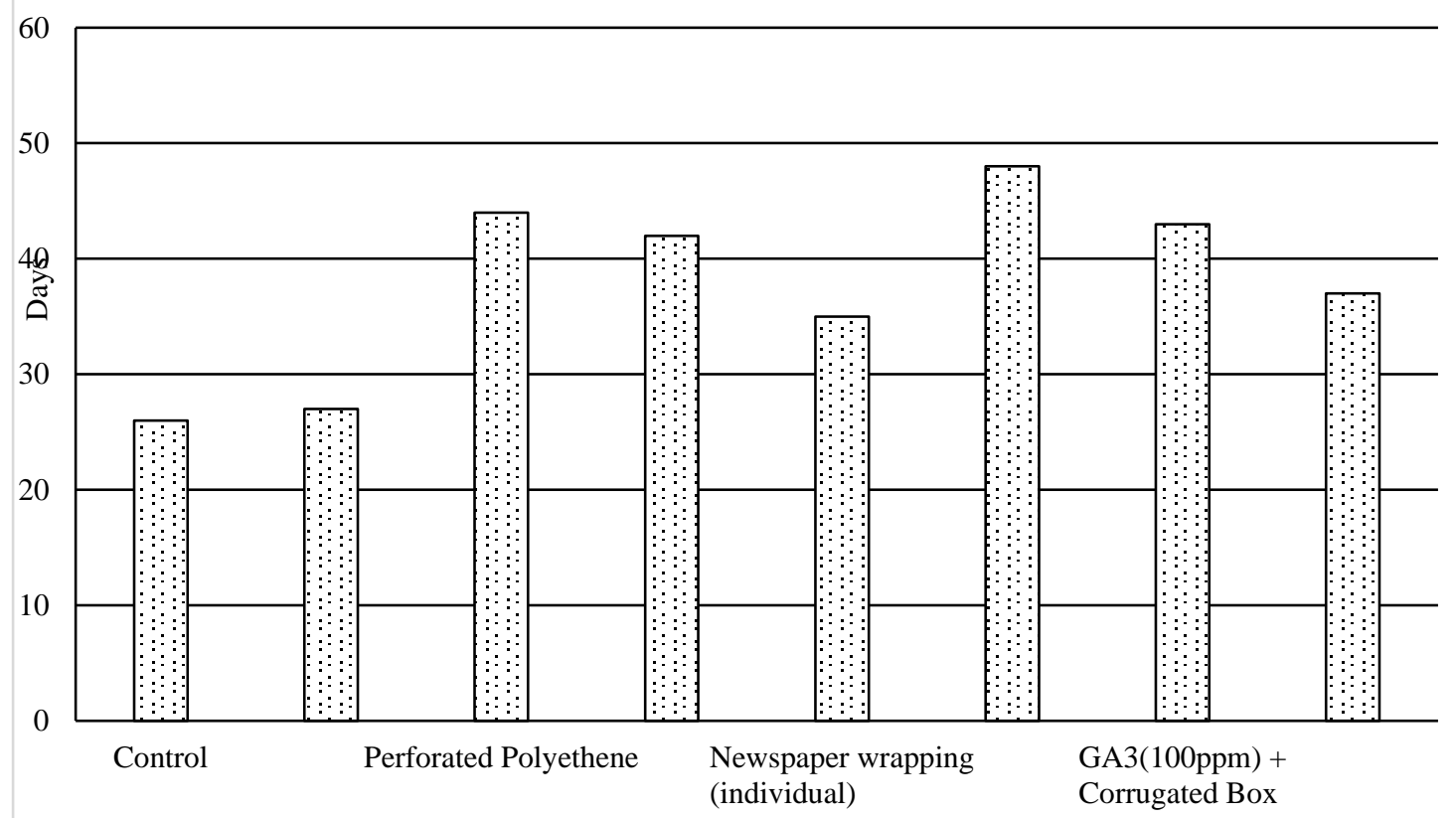

Figure 2: Shelf life of mandarin fruits as influence by different post-harvest treatment combination

\subsection{Conclusion}

Among the eight treatments combination, fruits treated with $\mathrm{GA}_{3}(100 \mathrm{ppm})$ in combination with perforated polyethene recorded minimum physiological loss in weight, high retention of Total soluble solids, titrable acidity and juice content. Fruits treated with $\mathrm{GA}_{3}(100 \mathrm{ppm})$ in combination with perforated polyethene attained shelf life of 48 days followed by perforated polyethene with a shelf life of 44 days. Hence fruits after harvest can be treated with GA $(100 \mathrm{ppm})$ and packed in perforated polyethene to control post-harvest loss and retain post-harvest attributes. In the light of experience gained during the course of investigation and results obtained, investigations are further needed with various dipping materials, plant growth regulators, botanical extracts and other commonly used packaging materials to enhance shelf life and retain quality traits.

\subsection{Acknowledgements}

The research was conducted as a part of Learning for Entrepreneurial experience supported by Prime Minister Agriculture Modernization Project. The author is thankful to all supervising committee, Project Implementation Unit (Citrus Zone), Udayapur and Agriculture and Forestry University, Rampur, Chitwan.

\subsection{References}

[1] P. Shrestha, and S. Verma, "Development and Outlook of Citrus industry in Nepal. In: Proceedings of National Horticulture Workshop", Nepal Horticulture Society, Kathmandu, Nepal, Pp. 48-57, 1999.

[2] FAO. Statistical Year Book. Retrieved from Food and Agriculture Report: http://www.faostat.fao.org/site/339/default.aspx..,2016.

[3] P. Rokaya, D. Baral, D. Gautam, and K. Paudyal, "Effect of packaging materials on fruit quality and shelf life of mandarin (Citrus reticuletaBlanco)", Nepalese Journal of Agricultural Sciences, 2015.

[4] NCRP. "Annual Report. Paripatle: Nepal Agriculture Research Council”, National Citrus Research Program, 2016.

[5] KFVMDB. “Kalimati Fruits And Vegetable Market Development Board”, Retrieved from http://kalimatimarket.gov.np/about-us, 2013.

[6] R.R. Bhattarai, R.K., Rijal, and P. Mishra, “Post-harvest losses in mandarin orange:A case study of Dhankuta District Nepal”, African Journal of Agricultural Research, Pp. 763-767, 2013.

[7] AITC. Krishi Diary. Kathmandu: Agriculture information and extension center, 2019.

[8] R. Pippal, “Effect of different plant growth regulators and packaging materials on shelf-life of Mandarin ( Citrus reticulata Blanco)”, 2011.

[9] A. Kader, "Increasing food availability and reducing postharvest losses of fresh produce. In Proceeding of 5th International postharvest symposium", F.Mencarelli \& P. Tonutti,Acta Horticulture, 2005.

[10] A.O.A.C. 2005. Official Methods of Analysis. Association of Official Analytical Chemists. Washington, USA, 2005.

[11] K. Gomez, and A. Gomez, "Statistical procedure for agricultural research”, JohnWiley \& Sons, 1984.

[12] J. Coggins, M. Anthony, and R. Fritts Jr, “The post harvest use of gibberlic acid on lemons”, Italy: Proc.Int.Soc.Citric, 1992.

[13] J.S. Bhullar, H.L. Farmahan, and R.P. Agnihotri, "Studies on storage behavior and extending the shelf life of Kinnow mandarin”, Prog. Hort., Vol. 13, No. 3-4, Pp. 115-119, 1981.

[14] B.P. Bhattarai, and R. Shah, "Effect of Different Packaging Materials on Post-Harvest Status of Mandarin (Citrus reticuleta Blanco)", Journal of Horticulture, Vol. 4, no. 218, Pp. 2376-0354, 2017. 
[15] M.R. Choudhary, and R.S. Dhaka, "Effect of different post-harvest treatments on quality of Kinnow mandarin fruits during storage", Haryana Journal of Horticultural Sciences, Vol. 34, no. 1/2, Pp. 39-41, 2005.

[16] G.S. Rana, R.K. Sharma, S.P. Garg, and S.K. Bhatia, "Effect of different storage conditions on shelf life of kinnow”, Research on Crops, Vol. 3, Pp. 403-405, 2002.

[17] S. Ahmad, and M.W. Siddiqui, "Postharvest treatments for preserving quality of 'kinnow' fruit under different storage conditions", Advances in Horticultural Science, 2013.

[18] D. Bujor, "Amendment to the petition to add gibberellic acid to the Nation". Libertyville: Valent BioScience Corporation, 2010.

[19] B. Mahajan, W. Dhillon, and M. Kumar, "Effect of Surface Coatings on the Shelflife and Quality of Kinnow Fruits During Storage", Journal of Postharvest Technology, Pp. 008-015, 2013.

[20] A. Bisen, S.K. Pandey, and N. Patel, "Effect of skin coatings on prolonging shelf life of kagzi lime fruits ( Citus aurantifolia Swingle )", J.food Sci. and Technol, Vol. 49, No. 6, Pp. 753-759, 2012.

[21] S.D. Jadhao, P.A. Borkar, A.L., Borkar, P.H. Bakane, and R.P. Murumkar, "Effect of different treatments and packaging materials on biochemical", Asian Journal of Bio Science, Vol. 3, No. 2, Pp. 247-250, 2008.

[22] P.R. Rokaya, "Effect Of Altitude And Various Pre And Postharvest Factors On Quality And Shelflife Of Mandarin(Citrus reticulata,Blanco)(Ph.D. thesis)", 2017.

[23] M. Ladaniya, "Citrus Fruit: Biology,Technology, and Evaluation First ed", Goa: Academic Press, 2008. 